VIRTUAL JUSTICE 
This page intentionally left blank 


\section{VIRTUAL JUSTICE}

the new laws of online worlds

\section{greg lastowk a}


Portions of this work are adapted, with substantial revisions, from my prior writings on virtual worlds, including "The Laws of the Virtual Worlds" (with Dan Hunter), 92 California Law Review 1 (2004); “Virtual Crimes” (with Dan Hunter), 49 New York Law School Law Review 293 (2004); “Amateur-to-Amateur” (with Dan Hunter), 46 William \& Mary Law Review 951 (2004); "Against Cyberproperty” (with Michael Carrier), 22 Berkeley Technology Law Journal 1485 (2007); “Decoding Cyberproperty”, 40 Indiana Law Review 23 (2007); "User-Generated Content \& Virtual Worlds," 10 Vanderbilt J. Entertainment \& Technology Law 893 (2008); “Planes of Power: EverQuest as Text, Game and Community," 9 Game Studies 1 (2009); and "Rules of Play," 4 Games \& Culture 379 (2009).

Copyright (๐ 2010 by Greg Lastowka. All rights reserved.

Subject to the exception immediately following, this book may not be reproduced, in whole or in part, including illustrations, in any form (beyond that copying permitted by Sections 107 and 108 of the U.S. Copyright Law and except by reviewers for the public press), without written permission from the publishers.

The author has made an online version of this work available under a Creative Commons Attribution-Noncommercial 3.0 License. It can be accessed through the author's Web site at http://www.chaihana.com/pers.html.

Yale University Press books may be purchased in quantity for educational, business, or promotional use. For information, please e-mail sales.press@yale.edu (U.S. office) or sales@yaleup.co.uk (U. K. office).

\section{(c) (i) (-)}

Set in Minion type by Westchester Book Services

Library of Congress Control Number: 2010926458

ISBN 978-0-300-14120-7

A catalogue record for this book is available from the British Library.

This paper meets the requirements of ANSI/NISO Z39.48-1992 (Permanence of Paper).

$\begin{array}{llllllllll}10 & 9 & 8 & 7 & 6 & 5 & 4 & 3 & 2 & 1\end{array}$ 
for Carol 
This page intentionally left blank 
If you have built castles in the air, your work need not be lost; that is where they should be. Now put the foundations under them.

—Henry David Thoreau

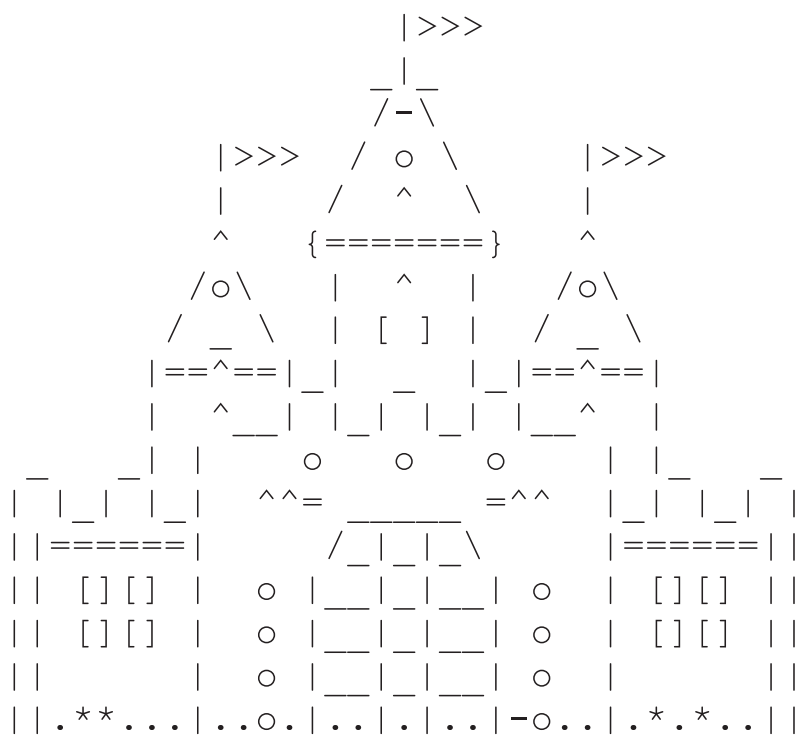


This page intentionally left blank 